\title{
Optimization, production and scale up of debittered kinnow beverage by $\alpha$-L-rhamnosidase producing yeast
}

\author{
Pratiksha Singh ${ }^{1 *}$, Param Pal Sahota ${ }^{1}$, Fatima Bhadra', Rajesh Kumar Singh ${ }^{2}$ \\ ${ }^{1}$ Punjab Agricultural University, Ludhiana-141004, India; ${ }^{2}$ National Bureau of Agriculturally Important Microorganisms, Uttar Pradesh- 275101, \\ India
}

\section{A B S T R A C T}

The $\alpha$-L-Rhamnosidase is used for debittering the citrus juice by hydrolyzing bitter naringin to nonbitter prunin and rhamnose. The present study was carried out on fermentative production of debittered kinnow (Citrus reticulata Blanco) beverage using $\alpha$-L-rhamnosidase producing yeast in order to utilize its immense potentiality in processed kinnow juice industry. The effect of percent yeast inoculum concentration $(0.25-1.25 \mathrm{v} / \mathrm{v})$, total soluble solids $\left(12-16^{\circ} \mathrm{B}\right)$, temperature $\left(15-35^{\circ} \mathrm{C}\right)$ and incubation time $(12-60 \mathrm{~h})$ were studied to optimize the production of $\alpha$-L- rhamnosidase enzyme from Clavispora lusitaniae in kinnow juice. Results indicated that yeast showing maximum rhamnosidase activity $\left(0.056 \mathrm{IU} \mathrm{mL}{ }^{-1}\right)$ in presence of yeast inoculum concentration $(0.75 \% \mathrm{v} / \mathrm{v})$, brix $\left(13^{\circ} \mathrm{B}\right)$, temperature $\left(30 \pm 5{ }^{\circ} \mathrm{C}\right)$ and incubation time $(48 \mathrm{~h})$. Further, these optimized conditions were used in upscale production of debittered kinnow beverage. The physicochemical parameters of freshly prepared beverage TSS $13.00 \pm 0.20{ }^{\circ} \mathrm{B}$, acidity $0.14 \pm 0.03 \%, \mathrm{pH} 3.40 \pm 0.10$, brix acid ratio $92.85 \pm 0.00$, limonin $6.90 \pm 0.10 \mathrm{ppm}$, naringin $443.00 \pm 10.00 \mathrm{ppm}$, total sugars $12.90 \pm 0.30 \%$, reducing sugars $2.42 \pm 0.20$ and ascorbic acid $27.80 \pm 1.00 \mathrm{mg} / 100 \mathrm{~mL}$. All the physicochemical parameters did not change significantly during storage. The decrease of naringin with storage was $443.00 \pm 10.00$ to $143.70 \pm 4.00 \mathrm{ppm}$ due to the $\alpha$-L-rhamnosidase activity of yeast. The percentage of ethanol and $\mathrm{CO}_{2}$ were $0.89 \pm 0.05 \%$ and $1.46 \pm 0.06$ bar after three months of storage. All the sensory parameters like taste, color, aroma, bouquet, flavor and astringency of kinnow beverage were stable at storage period of 90 days with almost no change in organoleptic sensation. Thus the technology presented here, a very less time consuming and safe for production of debittered kinnow beverage on large scale in citrus food industries.

Keywords: Kinnow beverage; Clavispara lusitaniae; $\alpha$-L-rhamnosidase; Debittered

\section{INTRODUCTION}

India is the second largest producer of fruits, with a production of 44.04 million tonnes of fruits from an area of 3.72 million hectares and holds third rank in respect of production of citrus fruits in the world. Kinnow, a hybrid of Citrus nobilis and Citrus delicosa is a prevalent citrus fruit in Punjab covering an area of 46,000 hectares with the production of 9.88 lakh tones NHM (2014).

Kinnow mandarin juice has high therapeutic value as antispasmodic, sedative, cytophylactic, digestive, anti carcinogenic, anti inflammatory and anti allergic. The health benefits of citrus fruit juices have been attributed due to the presence of bioactive and antioxidant compounds. A total of $150 \mathrm{~g}$ edible portion of orange provides $0.3 \mathrm{~g}$ fiber and $17 \mathrm{~g}$ of carbohydrates that can supply upto 73 kilocalories.

Kinnow juice turns bitter after extraction due to chemical naringin (flavanoid) and limonin (limonoid). Naringin is the major component in citrus fruit with very bitter taste and a threshold of $20 \mathrm{mgKg}^{-1}$ in water and detectable limit less than $1.5 \mathrm{mgKg}^{-1}$ (Chen et al., 2010). The presence of limonin and naringin in excess of $6 \mathrm{ppm}$ and $600 \mathrm{ppm}$ respectively has been established as an objectionable level of bitterness in processed citrus products such as juice, wine and vinegar (Guadagni et al., 1973).

Numerous techniques are used to reduce naringin such as adsorptive debittering (Fayoux et al., 2007), enzymatic hydrolysis (Puri and Kalra, 2005), poly-styrene divinyl

\footnotetext{
*Corresponding author:

Pratiksha Singh, Department of Microbiology, College of Basic Sciences and Humanities,

Punjab Agricultural University, Ludhiana- 141004. Phone: 9464145473, E-mail: singh.pratiksha23@gmail.com

Received: 15 March 2015; $\quad$ Revised: 07 April 2015; $\quad$ Accepted: 08 April 2015; $\quad$ Published Online: 09 April 2015
} 
benzene styrene resin treatment and $\beta$-cyclodextrin treatment (Mongkolkul et al., 2006). These techniques have limitations in altering nutrient composition either through chemical reactions or removal of nutrients, flavor and color etc. Another suitable debittering procedure is the stepwise hydrolysis of naringin by naringinase (Chen et al., 2010). The enzyme naringinase is composed of $a$-L-rhamnosidase (EC 3.2.1.40) and $\beta$-D-glucosidase (EC 3.2.1.21). Naringin (4',-5,7'-trihydroxyflavonone-7-rhamnoglucoside) is first hydrolyzed by $\alpha$-L-rhamnosidase activity of naringinase to rhamnose and prunin (one third of the bitterness of naringin) which can be further hydrolyzed into glucose and naringenin by the $\beta$-D-glucosidase component of naringinase. The potential application of rhamnosidase is used in the debittering of citrus fruit juices (Busto et al., 2007), manufacture of prunin from naringin, manufacture of L-rhamnose by hydrolysis of natural glycosides containing terminal L-rhamnose, enhancement of wine aromas by enzymatic hydrolysis of terpenyl glycosides containing L-rhamnose, elimination of hesperidin crystals from orange juices, conversion of chloropolysporin B to chloropolysporin C, the derhamnosylation of many L-rhamnose containing steroids for example, diosgene, desglucoruscin, ginsenosides- $\mathrm{Rg} 2$, etc. whose derhamnosylated products have their clinical importance (Feng et al., 2005).

The nutritional and therapeutic value of kinnow provides ample scope for processing into a value added fermented product with retention of organoleptic properties, nutritional attributes, characteristics sensory properties, flavor, aroma, texture and long shelf life. So, the aim of this work is to optimize and produce debittered kinnow beverage using $\alpha$-L-rhamnosidase producing yeast Clavispora lusitaniae KF633446.

\section{MATERIALS AND METHODS}

\section{Yeast culture}

Yeast strain producing rhamnosidase enzyme was isolated from whey beverage and identified as Clavispora lusitaniae (accession number- KF633446) on the basis of morphological, biochemical and $18 \mathrm{~S}$ rDNA sequence analysis.

\section{Screening of juice components for optimized $\alpha$-L- rhamnosidase production}

The physical and nutritional conditions were optimized following 'one-at-a-time' approach to enhance the yield of $\alpha$-L- rhamnosidase enzyme in diluted kinnow juice (juice:water; 1:1.5). The effect of percent inoculum concentration $(0.25,0.5,0.75,1$ and $1.25 \mathrm{v} / \mathrm{v})$, total soluble solids in $\left(12,13,14,15\right.$ and $\left.16^{\circ} \mathrm{B}\right)$, incubation time $(12,24,36,48$ and $60 \mathrm{~h})$ and temperature $(15,20$, 25,30 and $35^{\circ} \mathrm{C}$ ) on enzyme activity were evaluated. For each parameter optimization, three sets of independent experiments were carried out and the average value was reported.

\section{$\alpha$-L-Rhamnosidase enzyme assay}

$50 \mathrm{~mL}$ of the diluted kinnow juice in Erlenmeyer flask $(100 \mathrm{~mL})$ was aerobically cultured at $30 \pm 5{ }^{\circ} \mathrm{C}$ for $48 \mathrm{~h}$ on a rotary shaker $(150 \mathrm{rpm})$. After centrifugation $(12,000 \times \mathrm{g}$ for $10 \mathrm{~min}$ ), the supernatant was collected for measurement of rhamnosidase activity. The $\alpha$-L-rhamnosidase activity (RA) was determined using $\mathrm{p}$-nitrophenyl- $\alpha$-L-rhamnoside (p-NPR, Sigma) as the substrate (Romero et al., 1985). The reaction mixture consisted of $0.1 \mathrm{~mL}$ of $4.8 \mathrm{mM}$ p-NPR solution, plus $0.19 \mathrm{~mL}$ of $50 \mathrm{mM}$ citric acid/ $\mathrm{Na}$ citrate buffer, pH 5.0 and $10 \mu \mathrm{l}$ of enzyme or buffer (for the blank) and was incubated at $50^{\circ} \mathrm{C}$. Aliquots of $50 \mu \mathrm{L}$ from the reaction mixture were removed every $2 \mathrm{~min}$ and placed into $1.5 \mathrm{~mL}$ of $0.5 \mathrm{M} \mathrm{NaOH}$. These aliquots were kept in an ice bath until the absorbance was measured at $400 \mathrm{~nm}$ (Rajal et al., 2009). One unit (U) of enzyme activity was defined as the amount of enzyme required to release $1 \mu \mathrm{mol}$ of $\mathrm{p}$-nitrophenol per minute.

\section{Preparation of debittered kinnow beverage}

A debittered kinnow beverage was prepared under optimized conditions of inoculum concentration, TSS, temperature and incubation time.

\section{Extraction of juice}

Kinnow (Citrus reticulata Blanco) was procured from Department of Fruit Science, PAU, Ludhiana, Punjab, India. Fruits were washed in chlorinated water and then used for the extraction of juice. Juice was extracted aseptically under hygienic conditions by kinnow juice extractor.

\section{Preparation of sugar solution}

The sugar solution was prepared by boiling (500 g) granulated sucrose in one litre of water for $10 \mathrm{~min}$ and then allowed to cool at room temperature and stored aseptically in sterilized glass bottles.

\section{Inoculum preparation}

The inoculum was prepared in diluted juice with brix adjusted to $\left(13^{\circ} \mathrm{B}\right)$. A loopful culture of $24 \mathrm{~h}$ old yeast (Clavispora lusitaniae KF633446) was inoculated in $100 \mathrm{~mL}$ diluted kinnow juice in $250 \mathrm{~mL}$ Erlenmeyer flask and incubated at $30 \pm 5{ }^{\circ} \mathrm{C}$ for $24 \mathrm{~h}$ to achieve concentration of $10^{5}-10^{6}$ cells $\mathrm{mL}^{-1}$.

\section{Fermentation, bottling and storage}

The physico-chemical analysis ( $\mathrm{pH}, \%$ acidity, TSS, brix acid ratio, naringin, limonin and juice yield) of fresh kinnow juice was performed. Juice was diluted in the ratio 1:1.5 with water. Diluted juice was pasteurized at $82{ }^{\circ} \mathrm{C}$ for 
$15 \mathrm{sec}$, cooled and brix adjusted to $13{ }^{\circ} \mathrm{B}$ by adding sugar solution followed by inoculation of yeast i.e. $0.75 \%(\mathrm{v} / \mathrm{v})$. It was incubated for $48 \mathrm{~h}$ at $30 \pm 5^{\circ} \mathrm{C}$. The beverage was refrigerated for $24 \mathrm{~h}$, siphoned, bottled and stored in refrigerated conditions.

\section{Shelf life determination of kinnow beverage}

Shelf life fermented debittered kinnow beverage, stored at refrigerated temperature $\left(4^{\circ} \mathrm{C}\right)$ was studied and evaluated fortnightly for physicochemical, microbiological and sensory qualities.

\section{Physiochemical and microbiological analysis of kinnow juice and beverage}

The total soluble solids and $\mathrm{pH}$ of kinnow juice and beverage were determined by using Erma hand refractometer of $0-32{ }^{\circ} \mathrm{B}$ (Erma, Tokyo, Japan) and pH meter (ECIL, Hyderabad, type 101; Electronic Corporarion of India Ltd., Hyderbad, India). Total acidity expressed as citric acid was estimated following the procedure of AOAC (1999). Brix-acid ratio was calculated through dividing TSS value by total acidity of the juice and carbonated beverage. Total sugars were estimated by phenol sulphuric acid method (Dubois et al., 1956). Reducing sugars were estimated by the method of Miller (1959). The titration method using 2, 6-dichlorophenol indophenol dye was used to estimate ascorbic acid (AOVC 1996). The total phenolic content (TPC) was determined by spectrophotometry, using gallic acid as a standard, according the method described by Singleton and Rossi (1965). Limonin content was estimated by colorimetric method (Vaks and Lifshitz, 1981) and naringin content was estimated by Davis method (1947). Carbon dioxide volumes in beverage bottles were determined by Zahm and Nagel piercing device $\left(\mathrm{CO}_{2}\right.$ tester, Zahm and Nagel Co., Inc., Holland, New York, USA) and percent alcohol $(\mathrm{v} / \mathrm{v})$ was calculated by spectrophotometric determination method of ethanol (Caputi et al., 1968). Total yeast count was enumerated on GYE agar by serial plate dilution method.

\section{Sensory evaluation}

The organoleptic evaluation of kinnow beverages was done on the basis of appearance, taste, color, aroma, bouquet, body, flavor, astringency and overall acceptability by a panel of judges. Consumer acceptance for the products was evaluated on a nine point "Hedonic scale" (Amerine et al., 1965).

\section{Statistical analysis}

Statistical analysis was done by using CPCS1 software. Standard errors were calculated for all mean values. Differences were considered significant at the $p \leq 0.05$ level.

\section{RESULTS AND DISCUSSION}

\section{Screening of juice components for optimization of} $\alpha$-L-rhamnosidase production

Effect of percent inoculum concentration on $\alpha-L-$ rhamnosidase

Five different concentration of inoculum, $0.25 \%, 0.5 \%$, $0.75 \%, 1 \%$ and $1.25 \%(\mathrm{v} / \mathrm{v})$ of the standard stock inoculum was added in the juice and incubated for $24 \mathrm{~h}$ at room temperature. A differential response in rhamnosidase activity was obtained which showed that the $0.75 \%$ inoculum concentration exhibited maximum enzyme activity i.e. $0.057 \mathrm{IU} \mathrm{mL}^{-1}$ and $0.25 \%$ exhibited minimum rhamnosidase activity i.e. $0.023 \mathrm{IU} \mathrm{mL}^{-1}$ in kinnow juice (Fig. 1). Increase in inoculum size resulted in lesser enzyme production, due to the nutrient exhaustion and oxygen limitation. Similar results were also reported in Bacillus methylotrophicus (Mukund et al., 2014) and Staphylococcus xylosus MAK2 (Puri and Kalra, 2005) for naringinase production. Puri et al., (2005) studied the inoculum level of $3-15 \%(\mathrm{v} / \mathrm{v})$ in the salt medium with naringenin as an inducer to establish the effect of inoculum size on the naringinase production by $A$. niger. They observed that $10 \%(\mathrm{v} / \mathrm{v})$ inoculum was optimal for growth as well as naringinase production and the lag phase was also minimal.

\section{Effect of brix $\left({ }^{\circ} \mathrm{B}\right)$ on $\alpha$-L-rhamnosidase production}

In juice, brix was adjusted to $12,13,14,15$ and $16^{\circ} \mathrm{B}$ by adding sugar solution followed by inoculation of yeast i.e. $0.75 \%(\mathrm{v} / \mathrm{v})$. It was incubated for $24 \mathrm{~h}$ at room temperature. The effect of different ${ }^{\circ} \mathrm{B}$ on yeast rhamnosidase activity was tested and best ${ }^{\circ} \mathrm{B}$ for maximum rhamnosidase activity $\left(0.05 \mathrm{IUmL}^{-1}\right)$ was 13 in juice (Fig. 1). Further, with the increase in the initial sucrose concentration the rhamnosidase production was decreased which indicated that the higher sucrose concentration had an adverse effect on the enzyme production efficiency of the yeast. Naringinase activity was repressed by glucose, sucrose, citrate and lactose although these carbon sources supported excellent growth (Puri et al., 2005; Bram and Solomons, 1965). Production of $\alpha$-L-rhamnosidase by A. nidulans is mediated by carbon catabolite repression, which appears to be CreA-independent (Orejas et al., 1999). Further, it has been reported that the enzyme was not produced when $A$. kawachii was grown on $0.5 \%$ glucose as the sole carbon source (Koseki et al., 2008).

\section{Effect of incubation time on $\alpha$-L-rhamnosidase production}

Effect of different incubation time on enzyme activity was studied. Kinnow juice (brix $13{ }^{\circ} \mathrm{B}$ and inoculum concentration $0.75 \% \mathrm{v} / \mathrm{v}$ ) was incubated for different time periods $(12,24,36,48$ and $60 \mathrm{~h})$ at room temperature. Fig. 1 shows that the maximum enzyme activity in juice 


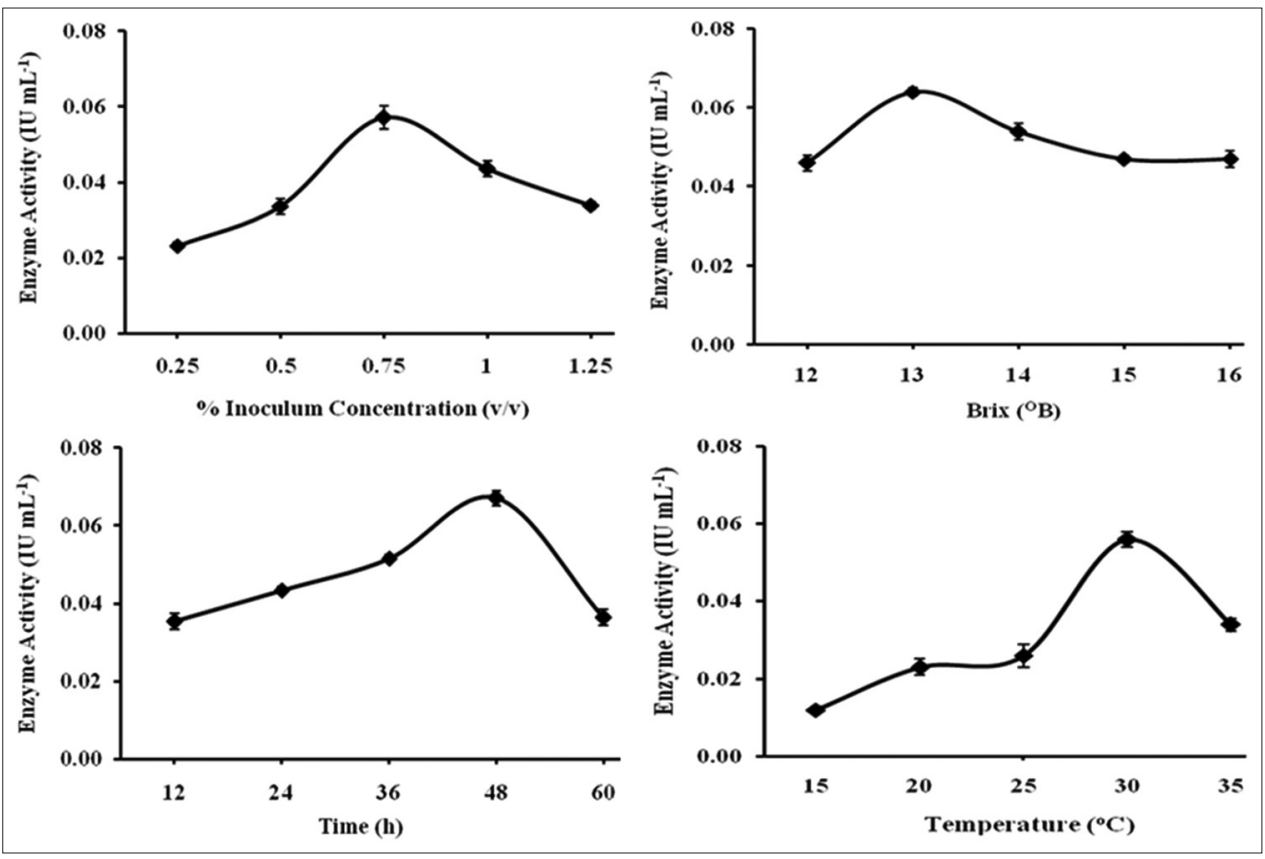

Fig 1. Effect of percent inoculum concentrations, brix $\left({ }^{\circ} \mathrm{B}\right)$, incubation time and temperature on $\alpha$-L-rhamnosidase production in kinnow juice.

was observed after $48 \mathrm{~h}$ of fermentation. Maximum naringinase production $\left(12.05 \mathrm{UL}^{-1}\right)$ was observed at $34 \mathrm{~h}$ of fermentation, which corresponds to a stationary phase of growth (Mukund et al., 2014). In the batch reactor, the maximum $\alpha$-rhamnosidase activity was obtained after 10 days from Penicillium ulaiense (Rajal et al., 2009). The reduction in production time is important because it decreases the fermentation costs and contamination with opportunistic microorganisms in scale up process.

Effect of temperature on $\alpha$-L-rhamnosidase production Five different levels of temperature were also studied. Kinnow juice (brix $13{ }^{\circ} \mathrm{B}$ and inoculum concentration $0.75 \% \mathrm{v} / \mathrm{v})$ was incubated at different temperatures $(15,20$, 25, 30 and $35^{\circ} \mathrm{C}$ ) for 48 h. Data in graph in Fig. 1 show the effect of changing temperature on enzyme activity. As the temperature increases, initially the enzyme activity increased while it decreased at higher temperatures at the same time. The decrease in enzyme activity may be the deactivation of enzyme due to the weakening of non covalent interactions that stabilize the protein structure. The optimum temperature for Pichia angusta rhamnosidase was observed at $40^{\circ} \mathrm{C}$ (Yanai and Sato, 2000). The reported temperature optima of $\alpha$-L-rhamnosidases are in the range of $40-80{ }^{\circ} \mathrm{C}$ though one bacterial $\alpha$-L-rhamnosidase active at $4{ }^{\circ} \mathrm{C}$ is reported (Orrillo et al., 2007).

\section{Physicochemical characteristics of kinnow juice (Citrus Reticulata Blanco)}

The physicochemical characteristics of fresh kinnow juice was evaluated on the basis of chemical analysis. The results are presented in Table 1 , showing TSS- $8.00 \pm 1.00^{\circ} \mathrm{B}$,
Table 1: Physicochemical characteristics of kinnow (Citrus reticulata Blanco)

\begin{tabular}{lc}
\hline Parameters & Kinnow juice \\
\hline TSS $\left({ }^{\circ} \mathrm{B}\right)$ & $8.00 \pm 1.00$ \\
Acidity $(\%)$ & $0.29 \pm 0.02$ \\
$\mathrm{pH}$ & $3.50 \pm 0.10$ \\
Brix-acid ratio & $27.58 \pm 1.00$ \\
Total sugars $(\%)$ & $8.90 \pm 0.10$ \\
Reducing sugars $(\%)$ & $2.00 \pm 0.50$ \\
Ascorbic acid $(\mathrm{mg} / 100 \mathrm{~mL})$ & $30.40 \pm 1.00$ \\
Total polyphenol content $(\mathrm{mg} \mathrm{GAE} / 100 \mathrm{~mL})$ & $58.40 \pm 2.00$ \\
Limonin $(\mathrm{ppm})$ & $7.40 \pm 0.20$ \\
Naringin $(\mathrm{ppm})$ & $421.80 \pm 10.00$ \\
Juice yield $(\%)$ & $55.00 \pm 5.00$ \\
\hline
\end{tabular}

Mean values \pm standard error of three independent experiments

titrable acidity- $0.29 \pm 0.02 \%, \mathrm{pH}-3.50 \pm 0.10$, brix acid ratio- $27.58 \pm 1.00$, total sugars- $8.90 \pm 0.10 \%$, reducing sugars- $2.00 \pm 0.50 \%$, ascorbic acid- $30.40 \pm 1.00 \mathrm{mg} / 100 \mathrm{~g}$, total polyphenol content- $58.40 \pm 2.00 \mathrm{mg}$ GAE/100 mL, limonin- $7.40 \pm 0.20 \mathrm{ppm}$, naringin- $421.80 \pm 10.00 \mathrm{ppm}$, juice yield $-55.00 \pm 5.00 \%$ and peel and pomace- $39.00 \pm 4.00 \%$. In kinnow fruit, the juice content was found to be in the range of $36.00 \%$ to $62.00 \%$ (Jagjiwan, 2001) and ascorbic acid content in the range of 13.30 to $46.90 \mathrm{mg} / 100 \mathrm{~mL}$ (Pruthi et al., 1983; Singh et al., 1978). The acidity, pH and TSS of kinnow juice were reported in the range of $0.28-0.51 \%, 4.20-4.28$ and $8.00-15.75 \%$ by Kaur (2002). The amount of reducing and nonreducing sugars has been found around 3.95\% and 3.65\% (Veldihus, 1971). The acceptability and higher sensory score of beverages is very much dependent on its physicochemical properties including appearance, flavor, acidity and TSS. There may 
be changes in the physicochemical characteristics and loss of some compounds that impart flavour and aroma to the beverages during pasteurization and storage (Jairath et al., 2012).

\section{Scale up of the optimized process in the laboratory bench scale fermenter}

The optimized process parameters (brix $13^{\circ} \mathrm{B}$, inoculum concentration $0.75 \% \mathrm{v} / \mathrm{v}$, temperature $30^{\circ} \mathrm{C}$ and incubation time $48 \mathrm{~h}$ ) for production of maximum rhamnosidase enzyme was used for preparation of fermented debittered beverage. The experiment was conducted in laboratory fermenter (capacity- 10L) at Department of Microbiology.

\section{Evaluation of microbiological and physicochemical properties of kinnow beverage during storage}

The results of microbiological and physicochemical properties of kinnow beverage during storage period of 90 days are summarized in Table 2 . The results showed a significant decrease in brix from $13.00 \pm 0.20^{\circ} \mathrm{B}$ to $11.20 \pm 0.30^{\circ} \mathrm{B}$ and brix acid ratio from $92.85 \pm 0.00$ to $19.31 \pm 0.00$. Similar results have been reported by Sarolia and Mukherjee, 2002 in their studies on lime juice, Khandelwal et al., 2006 during the fermentation of kinnow sera, cane and kinnow cane juice and Ahmed et al., 2008 in preparation of ready to serve mandarin (Citrus reticulata) diet drink. The increase in TSS content of juice during storage might be due to hydrolysis of polysaccharides into monosaccharide and oligosaccharides.

The $\mathrm{pH}$ also decreased from $3.40 \pm 0.10$ to $3.00 \pm 0.10$, while acidity increased from $0.14 \pm 0.03 \%$ to $0.56 \pm 0.01 \%$ after fermentation. $\mathrm{pH}$ is inversely proportional to the acidity of any medium. This decrease in $\mathrm{pH}$ and increase in acidity was attributed to formation of acidic compounds by degradation of reducing sugars (Zia, 1987; Akhtar et al., 2010). A similar result of decreasing $\mathrm{pH}$ was also reported by Saleem, 1980 and Ahmed, 2008.

The percentage decrease in total sugars was from $12.90 \pm 0.30 \%$ to $9.50 \pm 0.40 \%$ and percentage decrease in reducing sugars was from $2.42 \pm 0.20 \%$ to $1.32 \pm 0.10 \%$ at the end of 90 days. The sugars in citrus are mainly glucose, laevulose and sucrose. Similar results were also observed by Jairath, 2012 for preparation of amla beverage. The increase in total sugar content of juice during storage might be due to hydrolysis of polysaccharides into monosaccharide and oligosaccharides. Ascorbic acid (vitamin C) content was reduced from the initial concentration $27.80 \pm 1.00 \mathrm{mg} / 100 \mathrm{~mL}$ to $6.48 \pm 0.40 \mathrm{mg} / 100 \mathrm{~mL}$ after 90 days.

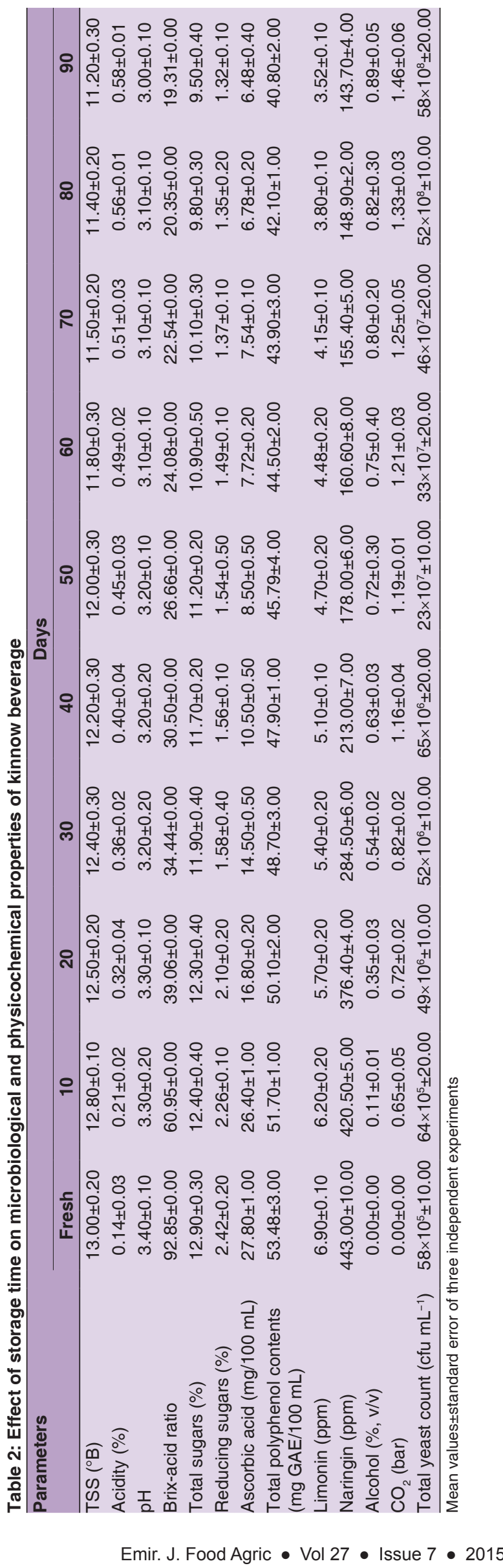


The decrease of ascorbic acid (vitamin C) in beverage during storage results from oxidation of ascorbic acid by ascorbic acid oxidase due to a combined effect of oxygen and light (Bhardwaj and Mukherjee, 2011; Jairath et al., 2012; Bhardwaj, 2013). The mean polyphenol contents of kinnow beverage were significantly decreased from $53.48 \pm 3.00 \mathrm{mg}$ GAE/100 $\mathrm{m} \mathrm{L}$ to $40.80 \pm 2.00 \mathrm{mg}$ $\mathrm{GAE} / 100 \mathrm{~mL}$ during storage.

The polyphenol contents of commercial fruit juices in the case of pineapple, orange and mango juices were higher than those of Thai beverages, reported by Abdullakasim et al., (2007). Different factors such as processing techniques, clarification and pasteurization can affect polyphenol contents of commercial juices. According to Ritter et al. (1992) and Karadeniz and Eksi (2001) reports, clarification also decrease the polyphenolic contents of commercial fruit juices. Polyphenol contents decreases constantly with the progress of the ripening, while in red coloured varieties it increases during the last ripening stage due to the maximal accumulation of anthocyanidines and flavonols (Marinova et al., 2005).

The decrease of limonin from $6.90 \pm 0.10$ to $3.52 \pm 0.10 \mathrm{ppm}$ might be due to production of $\mathrm{CO}_{2}$ during storage. Carbon dioxide at pressures of 21 to $41 \mathrm{MPA}$ at $30^{\circ} \mathrm{C}-60^{\circ} \mathrm{C}$ for $1 \mathrm{~h}$ resulted in an average removal of $25 \%$ of the limonin from navel orange juice (Kimball, 1987). A gradual increase in limonin content in juice blends with storage period might be due to conversion of a chemical compound limonate-a-ring lactone (non-bitter) in to limonin (bitter) in the juice (Premi et al., 1994). The decrease of naringin with storage was $443.00 \pm 10.00$ to $143.70 \pm 4.00 \mathrm{ppm}$ due to hydrolysis of naringin into rhamnose and prunin by $\alpha$-L-rhamnosidase activity of yeast. The alcohol production starts after 10 days and gradually increased from $0.11 \pm 0.01 \%$ to $0.89 \pm 0.05 \%$ after 90 days. The $\mathrm{CO}_{2}$ pressure $0.65 \pm 0.05$ bar starts building after 10 days and reached up to $1.46 \pm 0.06$ bar after 90 days. Sensitivity of yeast cells to ethanol marginally increased on decreasing the $\mathrm{pH}$ from 6.00-3.00. During fermentation process, $\mathrm{CO}_{2}$ alcohol and glycerol produced is proportional to the amount of sugar fermented.

The yeast strain produced large amount of glycerol at the expense of ethanol represent an advantageous alternative for the development of beverages with low ethanol content versus physical process which alter the organoleptic properties of the final product (Jairath et al., 2012). Total yeast count was increased from $58 \times 10^{5} \pm 10.00$ to $58 \times 10^{8} \pm 20.00 \mathrm{cfu} \mathrm{mL}^{-1}$ at the end of 90 days. This study indicated that the shelf life of beverage was 90 days.

\section{Evaluation of sensory attributes of beverage during storage}

The changes in sensory attributes like taste, color, aroma, bouquet, flavor and astringency of kinnow beverage were analyzed once every 10 days. All the sensory parameters were stable at storage period (90 days) with almost no change in organoleptic sensation (Table 3). Beverage was found to be acceptable up to 3 months of storage. The storage temperature can greatly affect the beverage tastes and smells. Lower temperatures will emphasize acidity and tannins while muting the aromatics. Higher temperatures will minimize acidity and tannins while increasing the aromatics. The presence of yeast in beverage gave a desirable freshness to the fermented beverage due to production of carbon dioxide and ethanol. Bhardwaj (2013) also reported that the low temperature and high relative humidity did not cause any change in qualitative characters and palatability of stored juice and helped in maintaining juice flavor, colour, TSS: acid ratio and sugars in balanced form than the ambient storage condition. In ambient condition change in colour of kinnow juice might be attributed to oxidation of phenolic compounds present in juice and maillard reaction between sugars and amino acids (Gonzalez, 2000). A gradual decrese in flavour and taste which may be due to the degradation of ascorbic acid and furfural production (Kausar et al., 2012) and may also be due to heat treatment applied during processing (Pruthi et al., 1984).

\section{CONCLUSION}

On the basis of results it can be concluded that the strain Clavispora lusitaniae is capable for producing debittered kinnow beverage using the optimized process parameters. The beverage can be stored for a period of 3 months at refrigeration temperature with minimum changes of all physico-chemical characters. Thus the technology presented here can also redress the problem of bitterness in food industries by reducing the naringin content of citrus juices.

\section{ACKNOWLEDMENTS}

This research was supported by Punjab Agricultural University (Department of Microbiology), Ludhiana.

\section{Author contributions}

P. S. involved in all the experiments; to measure $\alpha-\mathrm{L}$ rhamnosidase activity, optimization of parameters for beverage preparation and upscale production of kinnow beverage. P. P. S. was involved in overall planning and supervision. F. B. was involved in experiment; upscale production of kinnow beverage. R. K. S. was involved 
Singh, et al.: Production of debittered kinnow beverage

Table 3: Effect of storage time on organoleptic properties of kinnow beverage

\begin{tabular}{|c|c|c|c|c|c|c|c|c|c|c|}
\hline \multirow[t]{2}{*}{ Sensory attributes } & \multicolumn{10}{|c|}{ Days } \\
\hline & 0 & 10 & 20 & 30 & 40 & 50 & 60 & 70 & 80 & 90 \\
\hline Appearance & $7.40 \pm 0.10$ & $7.40 \pm 0.20$ & $7.30 \pm 0.10$ & $7.30 \pm 0.20$ & $7.40 \pm 0.20$ & $7.30 \pm 0.20$ & $7.30 \pm 0.10$ & $7.40 \pm 0.20$ & $7.30 \pm 0.20$ & $7.30 \pm 0.10$ \\
\hline Taste & $7.90 \pm 0.40$ & $8.10 \pm 0.30$ & $8.20 \pm 0.20$ & $8.10 \pm 0.20$ & $8.10 \pm 0.30$ & $7.80 \pm 0.20$ & $7.80 \pm 0.10$ & $7.80 \pm 0.40$ & $7.90 \pm 0.50$ & $7.90 \pm 0.40$ \\
\hline Colour & $8.00 \pm 0.20$ & $8.00 \pm 0.10$ & $8.00 \pm 0.30$ & $8.00 \pm 0.20$ & $7.90 \pm 0.40$ & $7.80 \pm 0.10$ & $7.80 \pm 0.10$ & $7.90 \pm 0.10$ & $7.80 \pm 0.20$ & $7.80 \pm 0.20$ \\
\hline Aroma & $8.60 \pm 0.30$ & $8.70 \pm 0.20$ & $8.75 \pm 0.10$ & $8.73 \pm 0.20$ & $8.70 \pm 0.20$ & $8.50 \pm 0.20$ & $8.70 \pm 0.10$ & $8.60 \pm 0.20$ & $8.40 \pm 0.20$ & $8.40 \pm 0.10$ \\
\hline Bouquet & $7.24 \pm 0.20$ & $7.25 \pm 0.10$ & $7.35 \pm 0.20$ & $7.38 \pm 0.10$ & $7.30 \pm 0.20$ & $7.36 \pm 0.20$ & $7.38 \pm 0.10$ & $7.35 \pm 0.20$ & $7.28 \pm 0.10$ & $7.28 \pm 0.20$ \\
\hline Body & $7.40 \pm 0.20$ & $7.45 \pm 0.30$ & $7.45 \pm 0.20$ & $7.48 \pm 0.30$ & $7.42 \pm 0.20$ & $7.45 \pm 0.30$ & $7.45 \pm 0.10$ & $7.42 \pm 0.10$ & $7.40 \pm 0.20$ & $7.48 \pm 0.10$ \\
\hline Flavor & $8.40 \pm 0.30$ & $8.50 \pm 0.10$ & $8.55 \pm 0.20$ & $8.60 \pm 0.20$ & $8.60 \pm 0.30$ & $8.00 \pm 0.20$ & $8.00 \pm 0.10$ & $7.50 \pm 0.10$ & $7.40 \pm 0.20$ & $7.20 \pm 0.10$ \\
\hline Astringency & $7.50 \pm 0.10$ & $7.60 \pm 0.20$ & $8.00 \pm 0.30$ & $8.40 \pm 0.10$ & $8.50 \pm 0.20$ & $8.50 \pm 0.30$ & $8.50 \pm 0.10$ & $8.20 \pm 0.20$ & $8.30 \pm 0.20$ & $8.20 \pm 0.20$ \\
\hline Overall acceptability & $8.20 \pm 0.10$ & $8.30 \pm 0.20$ & $8.40 \pm 0.10$ & $8.40 \pm 0.20$ & $8.20 \pm 0.10$ & $8.00 \pm 0.30$ & $7.90 \pm 0.30$ & $7.80 \pm 0.20$ & $7.80 \pm 0.10$ & $7.80 \pm 0.05$ \\
\hline
\end{tabular}

Mean value of three replicates. Like extremely 9 , Like very much 8 , Like moderately 7 , Like slightly 6 , Neither like/Dislike 5 , Dislike slightly 4 , Dislike moderately 3 , Dislike very much 2 , Dislike extremely 1

in planning and writing of experiment; optimization of parameters for beverage preparation.

\section{REFERENCES}

Ahmed, A., Ahmad, Z. A. Chatha and S. M. R. Dilshad. 2008. Studies on preparation of ready to serve mandarin (Citrus reticulata) diet drink. Pak. J. Agric. Sci. 45: 470-476.

Akhtar, S., M. Riaz, A. Ahmad and A. Nisar. 2010. Physico-chemical, microbiological and sensory stability of chemically preserved mango pulp. Pak. J. Bot. 42: 853-862.

Abdullakasim, P., S. Songchitsomboon, M. Techagumpuch, N. Balee, P. Swatsitang and P. Sungpuag. 2007. Antioxidant capacity, total phenolics and sugar contents of selected Thai health beverages. Int. J. Food Sci. Nutr. 58: 77-85.

Amerine, M. A., R. M. Pangborn and E. B. Roessler. 1965. Principles of Sensory Evaluation of Food. Academic Press, Elsevier, London, UK. p602.

AOAC. 1999. Official methods of analysis of the association of official analytical chemists. $16^{\text {th }}$ ed., $5^{\text {th }}$ Reversion. AOAC International, Gaithersburg

AOVC. 1996. Methods of Vitamin Assay. Association of vitamin chemists inc., Interscience Publishers, New York. p306-312.

Bhardwaj, R. L. 2013. Physico-chemical, sensory and microbiological quality of kinnow juice stored in refrigerated storage condition. Asian J. Dairy Food Res. 32: 203-213.

Bhardwaj, R. L. and S. Mukherjee. 2011. Effects of fruit juice blending ratios on kinnow juice preservation at ambient storage condition. Afr. J. Food Sci. 5: 281-286.

Bram, B. and G. L. Solomons. 1965. Production of the enzyme naringinase by Aspergillus niger. Appl. Microbiol. 13: 842-845.

Busto, M. D., V. Meza and N. P. Mateos. 2007. Immobilization of naringinase from Aspergillus niger cect 2088 in poly (vinyl alcohol) cryogels for the debittering of juices. Food chem. 104: 1177-1182.

Caputi, A. J. R., Ueda, M and T. Brown. 1968. Spectrophotometric determination of ethanol in wines. Am. J. Enol. Vitic. 19: 160165.

Chen, D., T. Niu and H. Cai. 2010. Optimizing culture medium for debittering constitutive enzyme naringinase production by Aspergillus oryzae jmu316. Afr. J. Biotechnol. 9: 4970-4978.

Davis, D. W. 1947. Determination of flavonones in citrus juice. Anal. Chem. 19: 46-48.

Dubois, M., K. A. Gills, J. K. Hamilton, P. A. Roberts and F. Smith.
1956. Colorimetric method for determination of sugars and related substances. Anal. Chem. 28: 350-356.

Fayoux, S. C., R. J. Hernandez and R. V. Holland. 2007. The debittering of navel orange juice using polymeric films. J. Food Sci. 72: 143-154.

Feng, B., B. Ma, L. Kang, C. Xiong and S. Wang. 2005. The microbiological transformation of steroidal saponins by Curvularia lunata. Tetrahedron. 61: 11758-11763.

Gonzalez, E. R. and S. Leeson. 2000. An investigation on the preservation of Kunun-zaki, an African fermented cereal based food drink. Acta Aliment. 29: 385-392.

Guadagni, D. G., V. P. Maier and J. G. Turnbaugh. 1973. Effect of some citrus juice constituent on taste thresholds for limonin and naringinin bitterness. J. Sci. Food Agric. 24: 1277-1288.

Jagjiwan, D. 2001. Physico-chemical debittering and processing of kinnow juice with by- product recovery. M.Sc Thesis, Thapar Inst. Eng. \& Technology, Patiala.

Jairath, S., P. P. Sahota and G. Pandove. 2012. Preparation of nonalcoholic naturally carbonated beverage using yeast isolate from whey beverage. Czech J. Food Sci. 30: 135-143.

Karadeniz, F. and A. Eksi. 2001. Elma suyunda fenolik bilesiklerin proses ve depolama sirasinda deg-isimi. Gida 26: 255-260.

Kaur, K. 2002. Application of novel juice extraction methods and bacterial utilization of limonin for control of bitterness in kinnow juice M.Sc Thesis, Thapar Institute of Engg \& Tech, Patiala.

Kausar, H., S. Saeed, M. M. Ahmad and A. Salam. 2012. Studies on the development and storage stability of cucumber-melon functional drink. J. Agric. Res. 50: 239-248.

Khandelwal, P., V. Kumar, N. Das and S. M. Tyagi. 2006. Development of a process for preparation of pure and blended kinnow wine without debittering kinnow mandarin juice. Internet J. Food Safety. 8: 24-29.

Kimball, D. A. and N. Seth. 1987. Changes in California naval orange juice during commercial debittering. J. Food Sci. 55: 273-274.

Koseki, T., Y. Mese, N. Nishibori, K. Masaki, T. Fujii, T. Handa, Y. Yamane, Y. Shiono, T. Murayama and H. lefuji. 2008. Characterization of an $\alpha$-L-rhamnosidase from Aspergillus kawachii and its gene. Appl. Microbiol. Biotechnol. 80: 1007-1013.

Marinova, D., F. Ribarova and M. Atanassova. 2005. Total phenolics and total flavonoids in Bulgarian fruits and vegetables. J. Univ. Chem. Technol. Metal. 40: 255-260.

Miller, G. L. 1959. Use of dinitrosalicylic acid reagent for determination of reducing sugar. Anal. Chem. 31: 426-428.

Mongkolkul, P., P. Rodart, T. Pipatthitikorn, L. Meksut and 
R. Sanguandeekul. 2006. Debittering of tangerine citrus Reticulata blanco juice by $\beta$-cyclodextrin polymer. J. Incl. Phenom. Macrocycl. Chem. 56: 167-170.

Mukund, P., P. D. Belur and Saidutta, M. B. 2014. Production of naringinase from a new soil isolate, Bacillus methylotrophicus: Isolation, optimization and scale-up studies. Prep. Biochem. Biotechnol. 44: 146-163.

NHM, 2014. World Wide Web Source for National Horticulture Mission data.

Orejas, M., E. Ibanez and D. Ramon. 1999. The filamentous fungus Aspergillus nidulans produce an $\alpha$-L-rhamnosidase of potential oenological interest. Lett. Appl. Microbiol. 28: 383-388.

Orrillo, A. G., P. Ledesma, O. D. Delgado, G. Spagna and J. D. Breccia. 2007. Cold-active $\alpha$-L-rhamnosidase from psychrotolerant bacteria isolated from a sub-antarctic ecosystem. Enzyme Microb. Technol. 40: 236-241.

Premi, B. R., B. B. Lal and V. K. Joshi. 1994. Distribution pattern of bittering principle in kinnow fruits. J. Food Sci. Technol. 3: $140-141$.

Puri, M. and S. Kalra. 2005. Purification and characterization of naringinase from a newly isolated strain of Aspergillus niger 1344 for transformation of flavoids. World J. Microbiol. Biotechnol. 21: 753-758.

Puri, M., A. Banerjee and U. C. Banerjee. 2005. Optimization of process parameters for the production of naringinase by Aspergillus niger MTCC 1344. Process Biochem. 40: 195-201.

Purthi, J. S., J. K. Mann and M. S. Teotia. 1984. Studies on utilization of kinnow and malta oranges. J. Food Sci. Technol. 21: 123-127.

Rajal, V. B., A. G. Cid, G. Ellenrieder and C. M. Cuevas. 2009. Production, partial purification and characterization of
a-I-rhamnosidase from Penicillium ulaiense. World J. Microbiol. Biotechnol. 25: 1025-1033.

Ritter, G., G. Maier, E. Schöplein and H. Dietrich. 1992. The application of polyphenol oxidase in processing of apple juice. In: Proceedings of the JIEP 92. XVI. Conference of the Group Polyphenols. Conference of the Group Polyphenols, Lisbao. Pp1-4.

Romero, C., A. Manjoan, J. Bastida and J. L. Iborra. 1985. A method for assaying the rhamnosidase activity of naringinase. Anal. Biochem. 149: 566-571.

Saleem, M. 1980. Studies on the preparation of comminuted citrus fruit beverage base. M.sc. Thesis, Univ. Agric., Faisalabad.

Sarolia, D. K. and S. Mukherjee. 2002. Comparative efficiency of different preservation methods in keeping quality of lime (Citrus aurantifolia) swingle juice during storage. Haryana J. Hort. Sci. 31: 185-188.

Singh, B. P., A. K. Gupta and B. S. Chundawat. 1978. Effect of various treatments on storage of kinnow fruits. Punjab Hort. J. 18: 61-65.

Singleton, V. L., A. Joseph and J. R. J. Rossi. 1965. Colorimetry of total phenolics with phosphomolybdic-phosphotungstic acid reagents. Am. J. Enol. Vitic. 16: 144-158.

Vaks, B. and A. Litshitz. 1981. Debittering of orange juice by bacteria which degrade limonin. J. Agric. Food Chem. 29: 1258-1261.

Veldhius, M. K. 1971. Fruit and Vegetable Juice Processing Technology. $2^{\text {nd }}$ ed. The Avi Publishing Company, Inc., Westport, CT.

Yanai, T. and M. Sato. 2000. Purification and characterization of a-L-rhamnosidase from Pichia angusta x349. Biosci. Biotechnol. Biochem. 64: 2179-2185.

Zia, M. A. 1987. Production and characterization of fruit juice blends of mango, pomegranate and guava. M. Sc. Thesis. Dept. Food Tech. Univ. Agric., Faisalabad. 